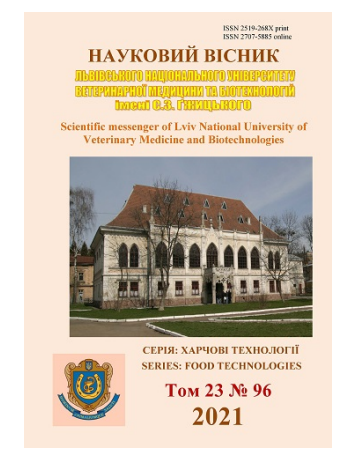

\author{
Науковий вісник Дьвівського національного університету \\ ветеринарної медицини та біотехнологій імені С.3. Гжицького. \\ Серія: Харчові технології \\ Scientific Messenger of Lviv National University \\ of Veterinary Medicine and Biotechnologies. \\ Series: Food Technologies

UDC 637.146:339

\title{
Development technologyof yogurt with coffee
}

\author{
N. B. Slyvka, I. V. Skulska \\ Article info \\ Received 14.05.2021 \\ Received in revised form \\ 16.06 .2021 \\ Accepted 17.06.2021 \\ Stepan Gzhytskyi National \\ University of Veterinary Medicine \\ and Biotechnologies Lviv, \\ Pekarska Str., 50, Lviv, \\ 79010, Ukraine. \\ Tel: +38-067-275-37-25, \\ +38-097-854-61-38 \\ E-mail:slyvkanat@ukr.net, \\ inna_skulska@ukr.net
}

Stepan Gzhytskyi National University of Veterinary Medicine and Biotechnologies Lviv, Lviv, Ukraine

Slyvka, N. B., \& Skulska, I. V. (2021). Development technologyof yogurt with coffee. Scientific Messenger of Lviv National University of Veterinary Medicine and Biotechnologies. Series: Food Technologies, 23(96), 61-66. doi: 10.32718/nvlvet-f9611

Formulations of yogurt flavored with coffee with a sugar content of 4 and $6 \%$ and instant coffee Nescafe Gold in the amount of $0.5,0.7$ or $0.9 \%$ were developed. The possibility of including in the formulation of low-fat yogurts protein enrichments, namely dry whey protein concentrate WPC 80 Milkiland in the amount of $1.5 \%$. A five-point scale has been developed to assess the organoleptic characteristics of new types of yogurt. It was found that the score of the consistency of the samples differed and decreased with increasing coffee content from 0.5 to $0.9 \%$. The sugar content did not affect the consistency, but higher taste scores were obtained with coffee-flavored samples with the addition of $5 \%$ sugar compared to $4 \%$. Yogurts with $0.7 \%$ coffee and $4 \%$ sugar and both yogurts with $0.9 \%$ coffee had the lowest scores compared to other yogurt samples. Changes in titratable acidity during yogurt fermentation and during storage were studied. It was found that the highest rate of increase of titratable acidity was registered for sample 3, which at $4 \mathrm{~h}$ of fermentation reached $98^{\circ} \mathrm{T}$ compared to others, which is explained by the content of 2.2-4.5\% chlorogenic acid and other organic acids in instant coffee. It was found that lactic acid accumulated during storage of yogurts with coffee. On the first day of storage, its content ranged from $0.135-0.200 \%$, and on the 15th day increased to 1.22-1.42\%. Such changes are natural, because lactic acid is a product of lactic acid microflora metabolism during lactose fermentation. It was investigated that the active acidity at the end of fermentation was 4.56 units. $p H$ against control -4.72 units. $p H$ and had a higher rate of decline compared to control. This can be explained by the mass fraction of lactose, which in the whey protein concentrate is $36 \%$. Also, this protein enrichment contains a large number of carboxyl groups, which increases the acidity of the clot and the finished product. All test samples were found to have better rheological properties due to the use of $1.5 \%$ whey protein concentrate and sugar in the formulations. The parameters of technological operations in the production of yogurt with coffee are substantiated.

Key words: yogurt, dry protein concentrates, yogurt technology, coffee, sugar.

\section{Розроблення технології йогурту з кавою}

\author{
Н. Б. Сливка, І. В. Скульська
}

Львівський національний університет ветеринарної медицини та біотехнологій імені С. 3. Гжицького, Львів, Україна

Розроблено реиептуру йогурту ароматизованого з кавою із вмістом иукру 4 та $6 \%$ i кави розчинної Nescafe Goldy кількості 0,5, 0,7 або 0,9\%. Доведено можливість включення до рецептури низькожирних йогуртів білкових збагачувачів, а саме сухого концентрату сироваткових білків WPC 80 Milkiland у кількості 1,5 \%. Створено п'ятибальну шкалу для оцінки органолептичних показників нових видів йогурту. Встановлено, що бальна оцінка консистенції у зразків відрізнялася $і$ зменшувалася зі збільшенням вмісту кави від 0,5 до 0,9\%. Вміст иукру не впливав на консистенцію, проте вищу оцінку смаку отримали зразки зі смаком кави $з$ додаванням 5 \% цукру порівняно з 4 \%. Йогурти з 0,7 \% кави і 4 \% иукру та обидва йогурти з 0,9\% кави мали найнижчі бали порівняно з іншими зразками йогурту. Досліджено зміни титрованої кислотності під час сквашування йогурту та впродовж зберігання. Встановлено, що найвищий темп наростання титрованої кислотності зареєстровано для зразка 3, який на 4 год сквашування досягнув $98^{\circ} \mathrm{T}$ порівняно з іншими, що пояснюється вмістом 2,2-4,5\% хлорогенової кислоти та інших органічних кислот у розчинній каві. Встановлено, що молочна кислота під час зберігання йогуртів з кавою накопичувалася. На перший день зберігання ї̈ 
вміст коливався в межах 0,135-0,200\%, а на 15 добу зріс до 1,22-1,42\%. Такі зміни закономірні, оскільки молочна кислота є продуктом метаболізму молочнокислої мікрофлори при зброджуванні лактози. Досліджено, щчо активна кислотність в кінці сквашування становила 4,56 од. рН проти контролю - 4,72 од. рН і мала вищий темп спадання порівняно з контролем. Це можна пояснити масовою часткою лактози, яка у концентраті сироваткових білківстановить 36 \%. Також цей білковий збагачувач містить велику кількість карбоксильних груп, що збільиує кислотність згустку і готового продукту. Встановлено, щяо всі дослідні зразки мали кращі реологічні властивості, щчо пов 'язано з використанням у рецептурах 1,5\% концентрату сироваткового білка та иукру. Обгрунтовано параметри технологічних операцій при виробництві йогурту з кавою.

Ключові слова: йогурт, сухий білковий концентрат, технологія йогурту, кава, иукор.

\section{Вступ}

Зараз в усьому світі спостерігається тенденція здорового харчування, яка пропагує споживання низькокалорійних, але водночас корисних продуктів (Hachak et al., 2018). У високорозвинених країнах близько 90 \% усієї молочної продукції - низькожирні молочні продукти, в тому числі йогурти. Вони сприяють кращому засвоєнню мінералів і вітамінів та зміцнюють імунітет (Zozulia \& Simonov, 2018; Haidei et al., 2020; Hachak et al., 2021).

Дослідження довели, що 100-200 г йогурту щодня дозволяють організму активніше виробляти інтерферон; бактерії, що містяться в ньому, підтримують діяльність лейкоцитів, допомагаючи їм краще захищати організм від інфекцій (Pinheiro et al., 2005; Reis et al., 2011; Hachak et al., 2021).

Йогурт забезпечує організм молочними білками: в 2-х склянках йогурту є $1 / 5$ добової норми білка для дорослої людини. Також йогурт багатий кальцієм ( $25 \%$ добової норми в 100 г), фосфором (15\% добової норми в 100 г), йодом, вітамінами $\mathrm{B}_{2}$ і $\mathrm{B}_{12}$, містить аскорбінову кислоту, холін, ретинол, вітамін РР, вітаміни $\mathrm{B}_{1}, \mathrm{~B}_{3}, \mathrm{~B}_{6}, \mathrm{D}$, органічні та жирні кислоти, а калію в ньому стільки ж, як в бананах. В йогурті міститься ще магній, натрій, сірка, залізо, марганець, хром, цинк, фтор.

У молочних продуктах жири відповідають за окремі реологічні показники готового продукту. Тому при розробці низькожирних продуктів виникає потреба вирішення такої проблеми, як збереження їхньої якості. Одним зі шляхів вирішення цієї проблеми $є$ використання білкових збагачувачів на основі сироваткових білків. Їх використання має позитивний вплив не тільки на формування структурно-механічних властивостей готового продукту, а й надання їм оздоровчих властивостей (Skulska \& Tsisaryk, 2020).

Білки молока, особливо сироваткові, за своїм амінокислотним складом належать до найбільш повноцінних серед інших тваринного походження (Bohdanov et al., 2003). Додавання сироваткових білків у харчові продукти особливо актуально в наш час, коли гостро відчувається нестача повноцінних білків у харчовому раціоні населення (Brenc \& Kozlov, 1981; Berhilevych, 2010).

На V Міжнародній конференції з молочної сироватки "Whey volution" (Париж, 2008 р.), у доповіді S. Jorgensena було зазначено, що амінокислотний склад концентратів сироваткових білків має позитивний вплив на функції шлунково-кишкового тракту і його мікрофлору, структуру тіла (співвідношення м'язової та жирової тканини), енергетичний метаболізм, імунітет, запальні процеси, а також сприяє зниженню маси тіла, підвищенню фізичної активності та синтезу білка м'язових тканин (Dmytrovska, 2010). Крім того, приблизно $14 \%$ сироваткових білків $\epsilon$ ініціаторами перетравлювання і беруть участь у синтезі більшості життєво важливих ферментів та гормонів (Chaharovskyi et al., 2013).

Сучасний споживач вимагає також постійного розширення асортименту йогуртів шляхом заміни класичного йогурту на унікальні ароматизовані йогурти бажаної текстури та з відмінною харчовою цінністю. При цьому перевагу надають натуральним. Таким ароматизатором і наповнювачем водночас може бути кава натуральна, яку ми обрали для створення нових видів йогурту.

3 одного боку, причина вибору кави як ароматизатора в йогурті полягає в тому, що більшість людей п’ють каву кілька разів на день, і можна припустити, що кавові йогурти будуть у більшому попиті (Didukh \& Didukh, 2006).

3 іншого боку, кава має багатий хімічний склад i низку біологічно активних речовин. Зокрема, кава містить 9,4-18 \% жирів, 4,1 \% засвоюваних вуглеводів, 9-19,2 \% білкових речовин, не менше ніж 1,0\% кофеїну, 5,5 \% дубильних речовин, 32,5-33,5 \% клітковини, ефіри кавової та хінної кислот, мінеральні речовини (калій, кальцій, фосфор, залізо та ін), вітаміни, органічні кислоти. Також у каві виявлено 18 амінокислот, зокрема і всі незамінні (Chuiko et al., 2013).

Метою наших досліджень $є$ розроблення технології кавових йогуртів із масовою часткою жиру $1 \%$ та обгрунтування передумов використання у їхній технології концентратів сироваткових білків. Для цього нам потрібно обгрунтувати дозування кавового наповнювача і цукру при виготовленні нового виду йогурту; дослідити зміни титрованої і активної кислотностей під час ферментації; визначити оптимальні параметри технологічних операцій виробництва нового продукту; визначити показники якості низькожирних йогуртів з кавою під час зберігання.

\section{Матеріал і методи досліджень}

Для виробництва йогурту ми використали коров'яче молоко, що відповідає вимогам до молокасировини згідно з ДСТУ 3662-97 “Молоко коров'яче незбиране. Вимоги при закупівлі”.

Для виготовлення йогурту вихідну сировину пастеризували за температури $95-97{ }^{\circ} \mathrm{C}$ з витримкою 23 с. Контрольним зразком служив йогурт натуральний без ароматизаторів та цукру.

У нормалізовану пастеризовану та охолоджену до температури $50{ }^{\circ} \mathrm{C}$ суміш вносили цукор у кількості 
$4 \ldots 6 \%$, після розчинення якого суміш охолоджували до $35-40{ }^{\circ} \mathrm{C}$. Потім дослідні зразки розділили на три групи, у кожну з яких вносили по 0,5; 0,7 або 0,9\% розчинної кави Nescafe Gold як ароматизатор. Концентрації кави і цукру були обрані на основі результатів попереднього сенсорного оцінювання.

Для стабілізації консистенції при виробництві низькожирних йогуртів було додано сухий концентрат сироваткових білків WPC 80 Milkiland у кількості $1,5 \%$.

Для заквашування використовували йогуртову культуру YF-L903, до складу якої входять Streptococcus salivarius subsp. thermophilus, Lactobacillus delbrueckii subsp. bulgaricus. Кількість КУО: 5х 10 12 . Рекомендована температура інкубації становить 35-45 ${ }^{\circ} \mathrm{C}$. Заквашену суміш розливали у стерилізовані скляні баночки ємністю 150 мл і сквашували при $42{ }^{\circ} \mathrm{C}$ до досягнення $\mathrm{pH} 4,7$.

Середній час ферментації становив приблизно 34 год. Після попереднього охолодження до температури 5-7 ${ }^{\circ} \mathrm{C}$ йогурти зберігали та аналізували згідно 3
ДСТУ 4343:2004 “Йогурти. Загальні технічні умови” (DSTU 4343:2004) на 1, 4, 7, 11 та 15 дні.

Таким чином, сформовано 3 дослідних зразки i контроль. Для кожного зразка ми брали однакову кількість суміші молока 150 мл, яку вже попередньо підготували:

Контроль - молочна основа 3 м. ч. ж. $1 \%+$ йогуртова культура YF-L903;

Варіант 1 - молочна основа 3 м. ч. ж. $1 \%+$ йогуртова культура YF-L903 + концентрат сироваткового білка $(5 \%)+0,5 \%$ кави + 4 \% цукру;

Варіант 2 - молочна основа 3 м. ч. ж. $1 \%+$ йогуртова культура YF-L903 + концентрат сироваткового білка (10\%) + 0,7 \% кави + 5 \% цукру;

Варіант 3 - молочна основа 3 м. ч. ж. $1 \%+$ йогуртова культура YF-L903 + концентрат сироваткового білка $(15 \%)+0,9 \%$ кави $+6 \%$ цукру.

Для оцінки органолептичних показників було створено 5-бальну шкалу, яка наведена у таблиці 1.

Таблиця 1

Шкала для оцінювання органолептичних показників дослідних зразків

\begin{tabular}{|c|c|c|c|c|}
\hline \multirow{2}{*}{ Показники } & \multicolumn{4}{|c|}{ Бали } \\
\hline & 5 & 4 & 3 & $1-2$ \\
\hline $\begin{array}{c}\text { Зовнішній } \\
\text { вигляд }\end{array}$ & $\begin{array}{c}\text { Глянцевий, відсутність } \\
\text { відділення сироватки, } \\
\text { немає бульбашки газу, } \\
\text { чистий }\end{array}$ & $\begin{array}{c}\text { Відсутність відділення } \\
\text { сироватки, відсутність } \\
\text { тріщин і бульбашок } \\
\text { газу, чистий }\end{array}$ & $\begin{array}{c}\text { Тьмяний, мало тріщин, } \\
\text { незначне відділення } \\
\text { сироватки,чистий }\end{array}$ & $\begin{array}{c}\text { Багато тріщин і бульба- } \\
\text { шок газу, виділення } \\
\text { сироватки відбулось, } \\
\text { брудний вигляд }\end{array}$ \\
\hline Запах & Кисломолочний, & 3 ароматом кави & $\begin{array}{c}\text { Відсутність кисломоло- } \\
\text { чного запаху }\end{array}$ & $\begin{array}{c}\text { Відсутність кисломолоч- } \\
\text { ного запаху та чужорід- } \\
\text { ність запаху }\end{array}$ \\
\hline Консистенція & $\begin{array}{c}\text { Густа, нормальної текс- } \\
\text { тури, однорідна, після } \\
\text { перемішування без } \\
\text { відділення сироватки }\end{array}$ & $\begin{array}{c}\text { Густа, нормальної текс- } \\
\text { тури, однорідна, після } \\
\text { перемішування деяке } \\
\text { відділення сироватки }\end{array}$ & $\begin{array}{c}\text { Не надто рідка, після } \\
\text { перемішування відді- } \\
\text { лення сироватки }\end{array}$ & $\begin{array}{c}\text { Занадто рідка, після } \\
\text { перемішування } \\
\text { відділення сироватки }\end{array}$ \\
\hline Смак & \multicolumn{2}{|c|}{ Звичайний смак йогурту з присмаком кави } & $\begin{array}{c}\text { Кислий, трохи гіркий, зі } \\
\text { стороннім смаком }\end{array}$ & $\begin{array}{c}\text { Занадто кислий, гіркий, } \\
\text { зі стороннім смаком }\end{array}$ \\
\hline
\end{tabular}

Таким чином, загальна оцінка йогурту повинна становити 20 балів за зовнішній вигляд, запах, консистенцію та смак.

У таблиці 2 наведено бальну оцінку дослідних зразків йогуртів 3 кавою.

Показники зовнішнього вигляду i запаху серед усіх йогуртів отримали найвищу кількість балів. Бальна оцінка консистенції відрізнялася і зменшувалася зі збільшенням кількості кави від 0,5 до 0,9\%. Вміст цукру не впливав на консистенцію, проте вищу оцінку смаку отримали зразки зі смаком кави з додаванням $5 \%$ цукру порівняно $34 \%$. Йогурти з $0,7 \%$ кави та
4 \% цукру та обидва йогурти з 0,9 \% кави мали найнижчі бали.

Під час зберігання в окремих зразках відбулися зміни у зовнішньому вигляді: неоднорідна консистенція, поява пластівців, значне виділення сироватки. Усі зразки характеризувалися злегка кислуватим смаком, але без сторонніх присмаків і запахів. У дослідних зразках легке відшаровування сироватки спостерігалося після 15 дня зберігання, тимчасом як у контролі - після 11 дня. Колір продукту залишався однаковим упродовж усього терміну зберігання.

\section{Таблиця 2}

Бальна оцінка дослідних зразків

\begin{tabular}{rccccc}
\hline Зразок & Зовнішній вигляд & Запах & Консистенція & Смак & Всього \\
\hline Контроль & 5 & 5 & 5 & 4 & 19 \\
Варіант 1 & 5 & 5 & 4 & 5 & 19 \\
Варіант 2 & 5 & 5 & 3 & 4 & 17 \\
Варіант 3 & 5 & 5 & 3 & 5 & 18 \\
\hline
\end{tabular}


При використанні сироваткових білків скорочується тривалість гелеутворення на стадії прихованої ферментації та флокуляції, а це прискорює процес згортання суміші. Можна припустити, що інші рецептурні компоненти (зокрема кава) теж можуть впливати на ці процеси, що веде до змін титрованої кислотності під час виготовлення нового виду йогурту.

Тому було досліджено титровану кислотність під час ферментації. Проби відбирали в динаміці через 1 , 2, 3 i 4 години. На рисунку 1 показано зміни титрованої кислотності під час сквашування.

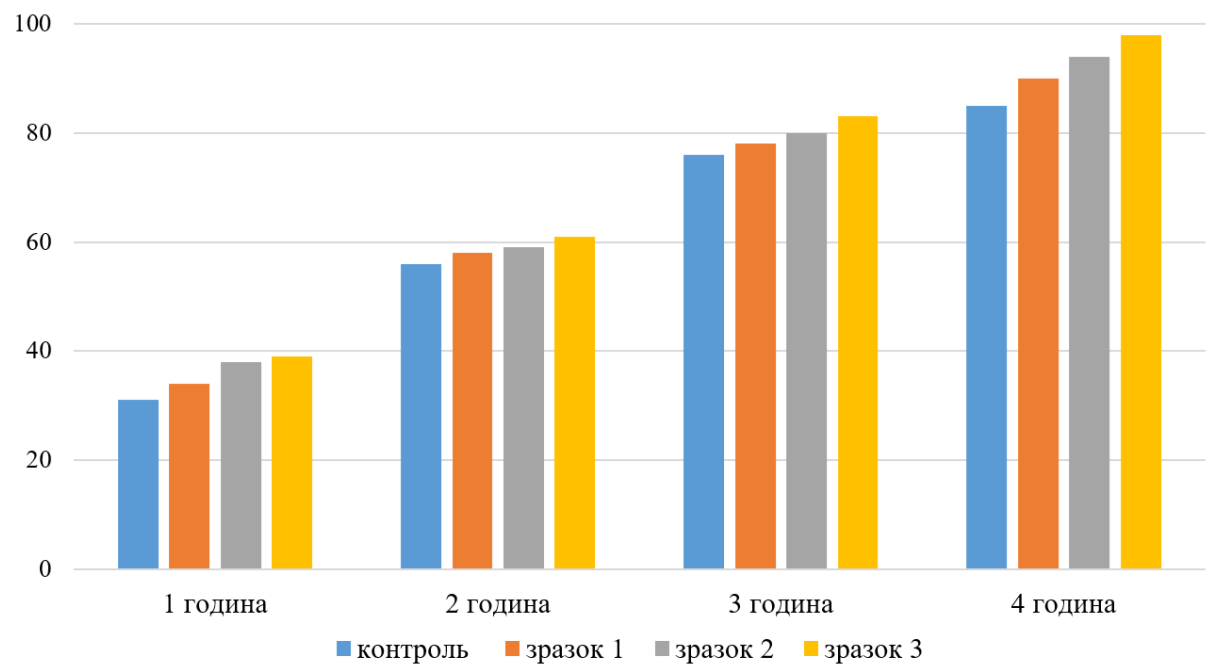

Рис. 1. Зміна титрованої кислотності під час сквашування

Найвищий темп наростання титрованої кислотності зареєстровано для зразка 3 , який на 4 год сквашування досягнув $98^{\circ} \mathrm{T}$ порівняно з іншими.

Кислотність розчинної кави може вплинути на це збільшення. Смажена кава, з якої готують розчинну каву, містить 2,2-4,5 \% хлорогенової кислоти та інші органічні кислоти, такі як оцтову, лимонну та яблучну.

Враховуючи специфіку нових рецептурних компонентів, як можливого джерела додаткового обсіменіння мікрофлорою, а також їхню фізикохімічну характеристику, досліджено основні показники якості йогуртів під час зберігання готових виробів. Тому було досліджено іiі зміни під час зберігання на 1, 4, 7, 11 та 15 доби ароматизованого йогурту. Титрована кислотність є критерієм оцінки якості молочних продуктів, а саме їхньої свіжості й натуральності.

На рисунку 2 показано зміни титрованої кислотності впродовж зберігання. Найвища титрована кислотність на 14 день зберігання зареєстрована у зразку 3, де найбільший вміст цукру і кави. Вона становила $141^{\circ} \mathrm{T}$ проти $122^{\circ} \mathrm{T}$ у контролі.

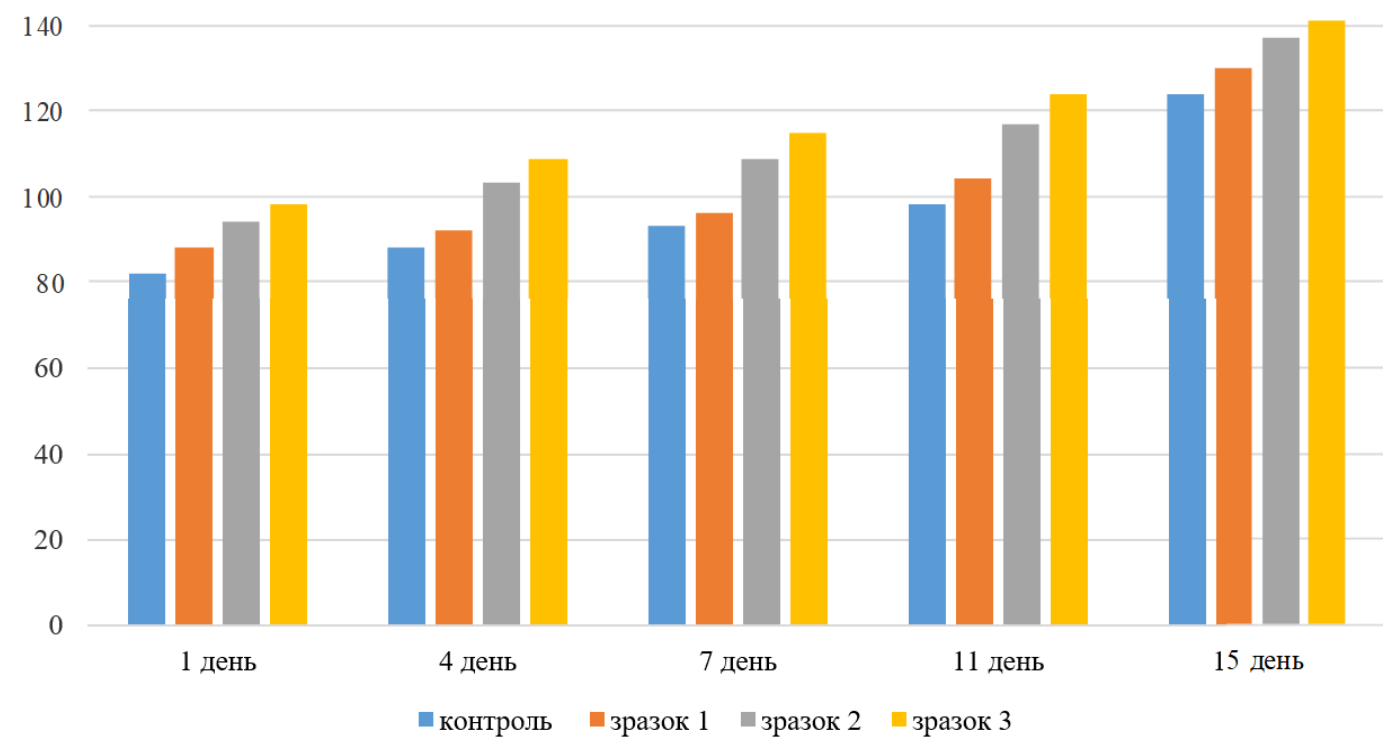

Рис. 2. Зміни титрованої кислотності впродовж зберігання 
Молочна кислота під час зберігання йогуртів 3 кавою накопичувалася.

На перший день зберігання іï вміст коливався в межах 0,135-0,200 \%, а на 15 добу зріс до 1,22 $1,42 \%$. Такі зміни закономірні, оскільки молочна кислота $\epsilon$ продуктом метаболізму молочнокислої мікрофлори при зброджуванні лактози.

На рисунку 3 показано зміни активної кислотності суміші під час сквашування. У зразку 3 активна кислотність мала вищий темп спадання порівняно 3 контролем.
В кінці сквашування активна кислотність цього зразка становила 4,56 од. $\mathrm{pH}$ проти контролю - 4,72 од. $\mathrm{pH}$.

3 отриманих результатів видно, що кислотність незначно підвищується у дослідних зразках. Це можна пояснити масовою часткою лактози, яка міститься у КСБ і становить $36 \%$. Також цей білковий збагачувач містить велику кількість карбоксильних груп, що збільшує кислотність згустку і готового продукту.

На рисунку 4 показано зміни $\mathrm{pH}$ йогурту під час зберігання.

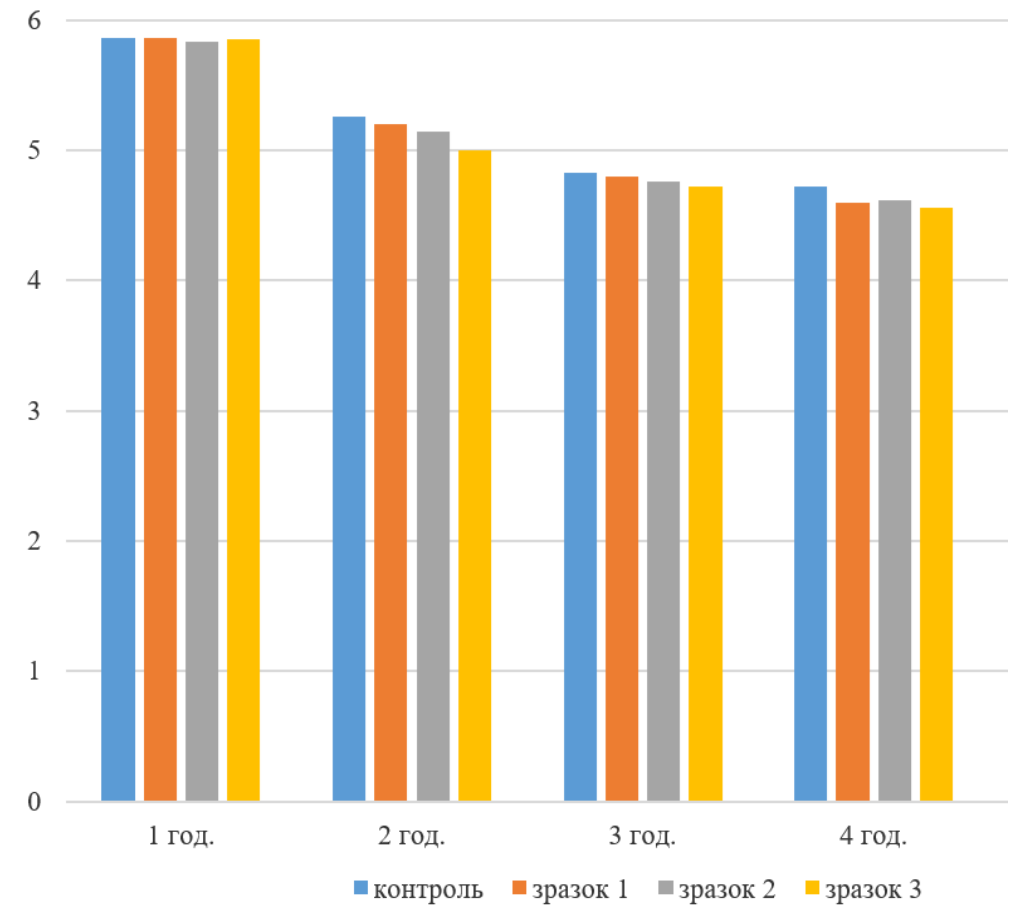

Рис. 3. Зміна активної кислотності суміші під час сквашування

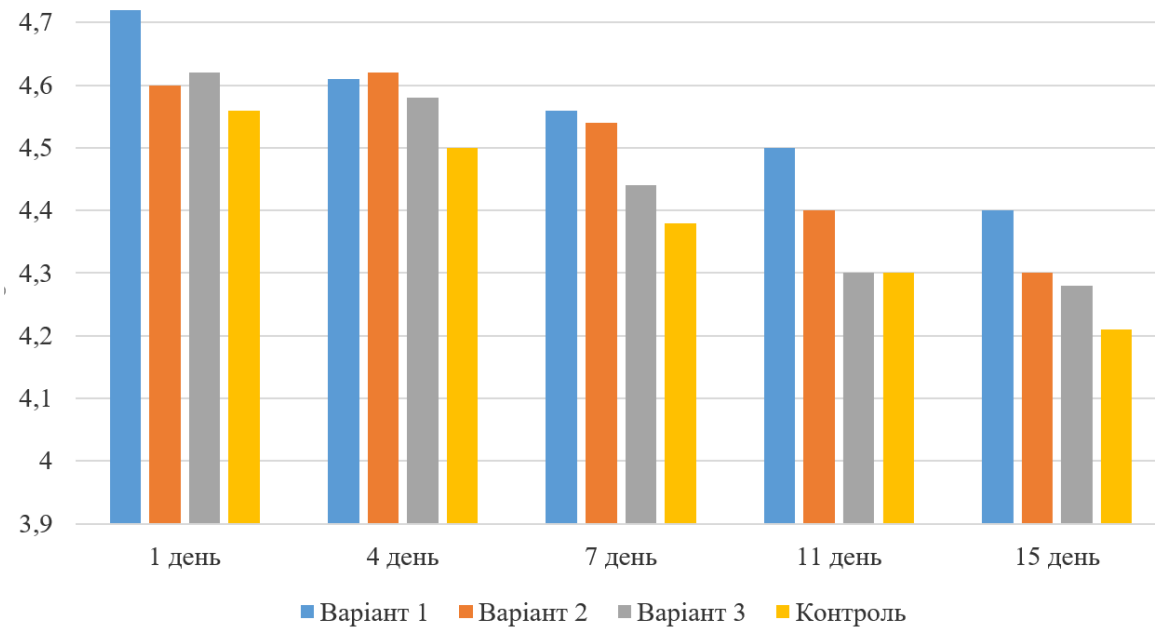

Рис. 4. Зміна активної кислотності суміші під час зберігання

Під час зберігання $\mathrm{pH}$ знижувався від 4,72 до 4,4 у контролі та найбільш виражено у зразку 3 - 3 4,56 до 4,21 .

\section{Висновки}

Розроблено рецептуру йогурту ароматизованого 3 кавою (кава розчинна Nescafe Gold кількістю 0,5, 0,7 та $0,9 \%)$ та цукром $(4 \ldots 6 \%$ від маси суміші). Також доведено можливість включення та доцільність використання у рецептурі низькожирних йогуртів білкових збагачувачів, а саме сухого концентрату сироваткових білків WPC 80 Milkiland у кількості 1,5\%, оскільки всі дослідні зразки мали кращі реологічні показники. Встановлено, що найвищий темп наростання титрованої кислотності зареєстровано для зразка 3 , 
який на 4 год сквашування досягнув $98^{\circ} \mathrm{T}$ порівняно 3 іншими, що пояснюється вмістом 2,2-4,5 \% хлорогенової кислоти та інших органічних кислот у розчинній каві.

Підсумовуючи, можна також зробити висновок, що нові ароматизовані йогурти можуть конкурувати на ринку молочної продукції, оскільки мають високі смакові якості.

\section{References}

Berhilevych, O. M. (2010). Mikrobiolohiia moloka ta molochnykh produktiv $\mathrm{z}$ osnovamy veterynarnosanitarnoi ekspe-rtyzy: navch. posib. za red. V. V. Kasianchuk. Sumy: Universytetska knyha (in Ukrainian).

Bohdanov, H. O. Kravtsiv, R.I., \& Mankovskyi, A. Ya. (2003). Tekhnolohiia pererobky moloka. Lviv: Spolom (in Ukrainian).

Brenc, M. Ja., \& Kozlov, V. N. (1981). Molochnye produkty, poleznye vsem. M.: Legkaja i pishhevaja promyshlenost' (in Russian).

Chaharovskyi, O. P. Tkachenko, N. A., \& Lysohor, T. A. (2013). Khimiia molochnoi syrovyny. Navch. pos. Odesa: "Simeks-print" (in Ukrainian).

Chuiko, A. M., Chuiko, M. M., \& Borysenko, I. V. (2013). Rozrobka tekhnolohii yohurtu funktsionalnoho pryznachennia $\mathrm{z}$ vykorystanniam naturalnykh pidsolodzhuvachiv i roslynnykh napovniuvachiv. Prohresyvna tekhnika ta tekhnolohii kharchovykh vyrobnytstv, restorannoho ta hotelnoho hospodarstv i torhivli, 1, 236-238.

Didukh, H. V., \& Didukh, A. V. (2006). Vykorystannia vtorynnoi molochnoi syrovyny u vyrobnytstvi molochnykh heroproduktiv. Molochnoe delo, 1, 16-19 (in Ukrainian).

Dmytrovska, H. P. (2010). Yohurty, kefiry ta produkty kefirni vitaminizovani dlia masovoho, spetsialnoho diietychnoho ta dytiachoho spozhyvannia. Molochnoe delo, 6(87), 24-26 (in Ukrainian).

DSTU 4343:2004. Yohurty. Zahalni tekhnichni umovy (in Ukrainian).

Hachak, Y., Gutyj, B., Nagovska, V., Slyvka, N., \& Ilnytska, A. (2018). Development of reciproces of dairy products of treatment and prophylaxic appointment with cryo powder. Scientific Messenger of LNU of Veterinary Medicine and Biotechnologies. Series: Food Technologies, 20(85), 70-75. doi: $10.15421 /$ nvlvet8513.

Hachak, Y., Nahovska, V., \& Gutyj, B. (2021). The use of cryopowder from seafood in the technology of thermostatic yogurt for therapeutic and prophylactic purposes. Scientific Messenger of LNU of Veterinary Medicine and Biotechnologies. Series: Food Technologies, 23(95), 83-90. doi: 10.32718/nvlvetf9514.

Hachak, Yu. R. (2014). Pererobka moloka ta vyrobnytstvo molochnykh produktiv u fermerskykh hospodarstvakh i v domashnikh umovakh. Kozak M. V. Lviv (in Ukrainian).

Haidei, O., Shuliak, S., Oleksiienko, I., Kyivska, G., \& Krushelnytska, O. (2020). Monitoring of gluten in dairy products. Scientific Messenger of LNU of Veterinary Medicine and Biotechnologies. Series: Food Technologies, 22(94), 8-12. doi: 10.32718/nvlvet-f9402.

Hrek, O., Krasulia, O., \& Pshenychna, T. (2016). Vplyv kontsentratu bilka na konsystentsiiu kyslomolochnoho napoiu. Prodovolcha industriia APK, 4, 27-32 (in Ukrainian).

Pinheiro, M. V. S., Oliveira, M. N., Penna, A. L. B., \& Tamime, A. Y. (2005). The effect of different sweeteners in low-calorie yogurts - A review. International Journal of Dairy Technology, 58(4), 193-199. doi: 10.1111/j.1471-0307.2005.00228.x.

Reis, R. C., Minim, V. P. R., Bolini, H., Dias, B. R. P., Min-im, L. A., \& Ceresino, E. B. (2011). Sweetness equiva-lence of different sweeteners in Strawberryflavored yogurt. Journal of Food Quality, 34, 163170. doi: 10.1111/j.1745-4557.2011.00378.x.

Skulska, I., \& Tsisaryk, O. (2020). Changes in protein substances of brynza cheese under the influence of partial replacement of salt with potassium chloride. Scientific Messenger of LNU of Veterinary Medicine and Biotechnologies. Series: Food Technologies, 22(93), 50-54. doi: 10.32718/nvlvet-f9309.

Zozulia, A., \& Simonov, M. (2018). Effect of storage life on the microbiological composition of yogurts. Scientific Messenger of LNU of Veterinary Medicine and Biotechnologies. Series: Food Technologies, 20(85), 119-122. doi: 10.15421/nvlvet8522. 